\title{
Effect of Bortezomib on Total Cholesterol, Triglycerides and Histopathology Abdominal Aorta in Rats of Atherosclerosis Model
}

\section{Efek Bortezomib terhadap Kadar Kolesterol Total, Trigliserida dan Histopatologi Aorta Abdominal pada Tikus Model Aterosklerosis}

\author{
Ismawati ${ }^{1}$, Ilhami Romus ${ }^{2}$, Esy Maryanti ${ }^{3}$, Nopi Permatasari ${ }^{4}$, Elfiah Luthfianty ${ }^{4}$ \\ ${ }^{1}$ Department of Biochmistry Faculty of Medicine Universitas Riau Pekanbaru \\ ${ }^{2}$ Department of Pathologi Anatomy Faculty of Medicine Universitas Riau Pekanbaru \\ ${ }^{3}$ Department of Parasitology Faculty of Medicine Universitas Riau Pekanbaru \\ ${ }^{4}$ Faculty of Medicine Universitas Riau Pekanbaru
}

\begin{abstract}
The effects of using proteasome inhibitors on atherosclerosis could be beneficial or detrimental. This study aimed to analyze the effects of proteasome inhibitors in the progression stage. Experimental animals (18 rats) were divided into three groups, namely control (C) as a group of rats given standard feed, $P 1$ as atherosclerosis-induced rat group, and P2 as atherosclerosis-induced rat group and given proteasome inhibitors. Proteasome inhibitor administered was bortezomib at a dose of $50 \mu \mathrm{g} / \mathrm{kgBW} /$ day intraperitoneally on day 1 and 3. After four days of treatment, the termination and measurement of serum total cholesterol, serum triglycerides, and abdominal aorta histopathology with hematoxylineosin staining were carried out. Serum total cholesterol levels were measured using the CHOD-PAP (Cholesterol OxidasePeroxidase Aminoantypirin) method, whereas serum triglyceride levels were measured using the GPO-PAP (glycerol phosphatase oxidase-phenol4-amino antipyrene peroxidase) method. Histopathological assessment was carried out with a scoring system in 9 fields of view with a 400x magnification, which was then averaged. The ANOVA test showed significant differences in serum total cholesterol, serum triglycerides, and abdominal aortic histopathology between atherosclerosis and control groups, but there were no significant differences in the administration of bortezomib in atherosclerosis except in serum triglyceride levels. It can be concluded that the administration of 50 $\mathrm{\mu g} / \mathrm{kg}$ bortezomib for four days in the rats model of the progression stage of atherosclerosis can decrease serum triglyceride levels, although it can not inhibit the formation of atherosclerotic lesions and has no effect on serum total cholesterol.
\end{abstract}

Keywords: Atherosclerosis, bortezomib, cholesterol, proteasomes, triglycerides

\begin{abstract}
ABSTRAK
Efek penggunaan inhibitor proteasom terhadap aterosklerosis, ada yang menguntungkan dan merugikan. Penelitian ini bertujuan untuk menganalisis efek inhibitor proteasom pada tahap progresi aterosklerosis. Hewan coba (18 ekor tikus) dibagi menjadi 3 kelompok yaitu kontrol $(\mathrm{K})$ tikus yang hanya diberi pakan standar, $\mathrm{P}_{1}$ yaitu kelompok tikus yang diinduksi aterosklerosis, serta kelompok $\mathrm{P}_{2}$ yaitu kelompok tikus yang diinduksi aterosklerosis dan diberikan inhibitor proteasom. Inhibitor proteasom yang diberikan yaitu bortezomib dengan dosis $50 \mu \mathrm{g} / \mathrm{kgBB} /$ hari secara intra peritoneal pada hari ke-1 dan 3. Setelah 4 hari perlakuan dilakukan terminasi dan pengukuran kadar kolesterol total serum, trigliserida serum, serta penilaian histopatologi aorta abdominal dengan pewarnaan hematoksilin eosin. Kadar kolesterol total serum diukur dengan metode CHOD-PAP (Cholesterol Oxidase-Peroxidase Aminoantypirin), sedangkan kadar tigliserida serum diukur dengan metode GPO-PAP (glycerol phosphatase oxidase-phenol4-amino antipyrene peroxidase). Penilaian histopatogi dilakukan dengan sistem skoring pada 9 lapangan pandang dengan pembesaran 400x yang kemudian dirata-rata. Uji ANOVA menunjukkan perbedaan kadar kolesterol total serum, trigliserida serum dan histopatologi aorta abdominal yang bermakna antara kelompok dengan ateroskeloris dibandingkan kontrol, tetapi tidak terdapat perbedaan yang bermakna pemberian bortezomid pada aterosklerosis kecuali kadar trigliserida serum. Dapat disimpulkan bahwa pemberian bortezomib $50 \mu \mathrm{g} / \mathrm{kg}$ selama 4 hari pada tikus model aterosklerosis tahap progresi dapat menurunkan kadar trigliseida serum, meskipun tidak dapat menghambat terbentuknya lesi aterosklerosis dan tidak berpengaruh terhadap kadar kolesterol total serum
\end{abstract}

Kata Kunci: Aterosklerosis, bortezomib, kolesterol, proteasom, trigliserida

Correspondence: Ismawati. Department of Biochmistry Universitas Riau Pekanbaru, JI. Diponegoro No. 1, Pekanbaru Tel. 085217065890 Email:ismawati75@yahoo.com 


\section{INTRODUCTION}

Atherosclerosis is an inflammatory disease in the arteries that becomes a major cause of cardiovascular disease. Globally, cardiovascular diseases, namely coronary heart disease and cerebrovascular disease (especially ischemic stroke), are the main $(84.5 \%)$ and third $(28.2 \%)$ causes of death, respectively (1). In Indonesia, Basic Health Research in 2013 showed that cardiovascular diseases were the leading cause of death in Indonesia, comprising $36.2 \%$ of all causes of death (2).

Atherosclerosis is an inflammatory process that takes place progressively in medium-sized arteries. Accumulation of leukocytes in the subendothelial space is an early step in atherogenesis $(3,4)$. Based on clinical symptoms, atherosclerosis consists of initiation, progression, and complication stages. This process that occurs quietly only shows symptoms if it has entered the complication stage, such as chest pain and even sudden death (5).

The cause of atherosclerosis is multifactorial, both local and systemic factors, which further induce damage to vascular function. Hypercholesterolemia and, more specifically, increased low-density lipoprotein (LDL) concentration are important factors for atherosclerosis. Hypercholesterolemia is associated with an increase in LDL transcytosis through the vascular endothelium that causes LDL particle accumulation in the subendothelial chamber. Low-density lipoprotein particles subsequently experience medications into aggregation, glycosylation, enzymatic proteolysis, or oxidation. Hypertriglyceridemia will cause changes in size, density, distribution, and composition of LDL so that it becomes smalldense LDL that is more atherogenic. This condition increases the atherogenicity and retention in the blood vessel intima. Low-density lipoprotein retention is a key process of atherosclerosis initiation $(6,7)$.

Initiation stage of atherosclerosis is characterized by endothelial dysfunction and endothelial activation occurs due to the increase of inflammation and oxidative stress. At the stage progression of atherosclerosis, the formation of a layer of foam cells and vascular smooth muscle cells (VCMCs) proliferation occurs. Advance atherosclerosis (complication stage) is characterized by plaque rupture, thrombus formation, and complete or not complete occlusion. This happens due to a decrease in cell viability and an increase in the destructive inflammatory response (7).

Proteasome is an enzyme complex that primarily involved in degrading proteins, that plays a crucial role in the regulation of many cellular processes. 26S proteasome complex is formed by the catalytic 20S core proteasome and two19s regulatory particles. Electron microscopy analysis shows that the $20 \mathrm{~S}$ proteasome is cylindrical, composed of 4 rings. Each ring is arranged by 7 subunits. Three subunits of the ring namely 1, 2 and 5 have different active sites, respectively caspase like, trypsin like and chimotrypsin like (8).

Proteasome plays a role in the three main mechanisms in atherosclerosis, namely inflammation, proliferation, and apoptosis. Mostly, by activation of nuclear factor KB (NF$\mathrm{KB}$ ) which further regulates the expression of various genes of many modulators of the inflammatory and immune responses, including the adhesion molecules E-selectin and intercellular adhesion molecule-1 (ICAM-1) and cytokine. Adhesion molecules will mediate adhesion of monocytes then migrate and diapedesis. The interaction of monocyte cells with endothelial cells will stimulate production of Monocyte Metalloproteinase Matrix (MMP 9) to penetrate endothelial cells. Monocytes further differentiated into macrophages in response to Macrophage ColonyStimulating Factor (M-CSF) and other stimuli. Uptake of oxLDL particles by macrophages mediated by scavenger receptor which results in the formation of foam cells. Subsequently formed foam cell layers due to the inhibition of macrophage apoptosis due to increased degradation of p53 by proteasomes (7). Research by Ismawati, et al. (9) identified an increase in the expression of proteasomes in blood vessels at each stage of atherosclerosis, and the highest increase occurred in the progression stage.

Proteasome inhibitors are compounds that can inhibit the proteasome pathway. Bortezomib is the first-developed proteasome inhibitor and has been used for cancer therapy since 2003 (10). Bortezomib is competitive inhibitor and binds to the cata lytic sites of proteasome. The boronic acid group in bortezomib can bind and form a complex with the active site of threonine hydroxyl group in the $\beta 5$-subunit and block the chymotrypsin-like activity of the proteasome $(11,12)$. Several studies on the effects of proteasome inhibitors on atherosclerosis show different effects on the use of these proteasome inhibitors on atherosclerosis, some are beneficial but some give adverse effects that could be affected by differences in organ response, atherosclerosis stage, cell type, administration mode, and the dose of proteasome inhibitors used against atherosclerosis (13). The use of a $50 \mu \mathrm{g} / \mathrm{kg}$ bortezomib proteasome inhibitor for six weeks in LDLR -/- rats suppresses the formation of early atherosclerotic lesions (14). However, administering bortezomib with the same dose to LDLR -/- rats with advanced atherosclerotic lesions has no therapeutic effect (15).

In this study, the experimental animal model used was white rats. Rats were chosen because of several advantages that were practical, easy to obtain, omnivorous, more human-like than using rabbits. Even though rats are resistant to atherosclerosis, with modifications such as administration of thiouracil, vitamin D3, or adrenaline together with high cholesterol feed, rats can be induced into atherosclerosis (9). Research by Ismawati et al. (9) was succeeded in obtaining the atherosclerosis model for each stage of atherosclerosis, and, in this study, induction was carried out for the progression stage.

The treatment of atherosclerotic with bortezomib in animal models yielded partly opposing results, depending on the stage of the atherosclerotic. Based on the previous study, the highest expression proteasome was obtained in the stage of progression, so inhibit proteasome function by using bortezomib potential to attenuates atherosclerosis. However, no research has as yet studied the effects of bortezomib on progression stage of atherosclerosis. The current study has been designed to figure out more about the effect of bortezomib administration on serum total cholesterol, serum triglycerides, and aortic histopathology in rats model of atherosclerotic. This research was important as a basis for the development of bortezomib as a therapy for atherosclerosis.

\section{METHOD}

This study received ethics approval from the Medical and Health Research Ethics Unit with a certificate of ethical review number 132/UN.19.5.1.1.8/UEPKK/2019. This study used 18 male Wistar rats aged 2-3 months, which 
were randomly divided into three groups, namely the control group (C), the atherosclerosis group (P1), and the atherosclerosis + bortezomib group (P2). Atherosclerosis induction was done by administering vitamin D3 $(700,000$ $\mathrm{IU} / \mathrm{kg}$ ) orally by gastric intubation on day 1 and atherogenic diet in the form of $2 \%$ cholesterol, $5 \%$ goat fat, and $0.2 \%$ cholic acid for four days. Atherogenic feed was given in the pellet form of $20 \mathrm{~g} /$ day/rat (9). Bortezomib was given at a dose of $50 \mu \mathrm{g} / \mathrm{kgBW} /$ day intraperitoneally on day 1 and 3 (13).

On day 4 , the termination was performed by anesthesia using ether vapor, and the blood was taken from the heart and abdominal aortic tissue for total serum cholesterol, serum triglycerides, and abdominal aortic histopathology examinations. Total cholesterol levels in animal serum were measured using a spectrophotometer with the CHOD-PAP (Cholesterol Oxidase-Peroxidase Aminoantypirin) method, while serum triglyceride levels were measured using a spectrophotometer with the GPOPAP (glycerol phosphatase oxidase-phenol4-amino antipyrene peroxidase) method. Histopathological examination of the abdominal aorta was done using hematoxylin-eosin staining by scoring: 0 (unimpaired); 1 (macrophages, foam cells); 2 (smooth muscle proliferation, medial lipid infiltration, and fibrosis/calcification); 3 (surface defects: fissure/ulceration/hematoma/ thrombus) $(9,16)$. The assessments were carried out by an anatomic pathologist with a light microscope on nine field of view with a 400x magnification. Scores of each microscopic slide were summed and averaged (16). To compare the levels of total cholesterol, triglycerides, and abdominal aortic histopathology between groups, the ANOVA statistical test was performed and continued with post-hoc test with a significance level of $p<0.05$.

\section{RESULTS}

\section{Serum Total Cholesterol and Triglyceride Levels}

Figure $1 \mathrm{~A}$ shows total cholesterol levels of serum in the three groups. The mean level of serum total cholesterol for atherosclerosis group (P1) was $95.02 \pm 5.9 \mathrm{mg} / \mathrm{dl}$, the highest level of all our study groups. In contrast, rats in control group (C) mean levels of $64.61 \pm 1.8 \mathrm{mg} / \mathrm{dl}$, the lowest level of all groups. The mean level of serum total cholesterol for atherosclerosis+bortezomib group (P2) was $88.79 \pm 7.7 \mathrm{mg} / \mathrm{dl}$. The difference of serum cholesterol total was significant between atherosclerosis group (P1) and control group (C) ( $p=0.002)$. In contrary, no significant different $(p=0.455)$ was found between atherosclerosis +bortezomib group (P2)and atherosclerosis group (P1).

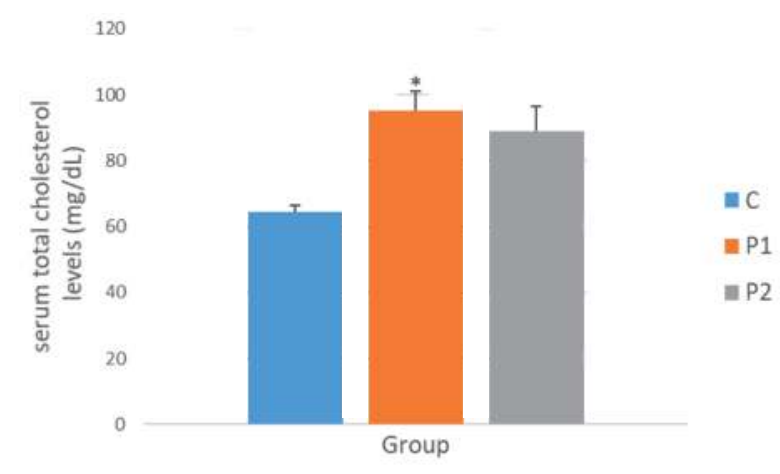

Figure 1. Graph of serum total cholesterol (a) and triglyceride levels (b) in each group

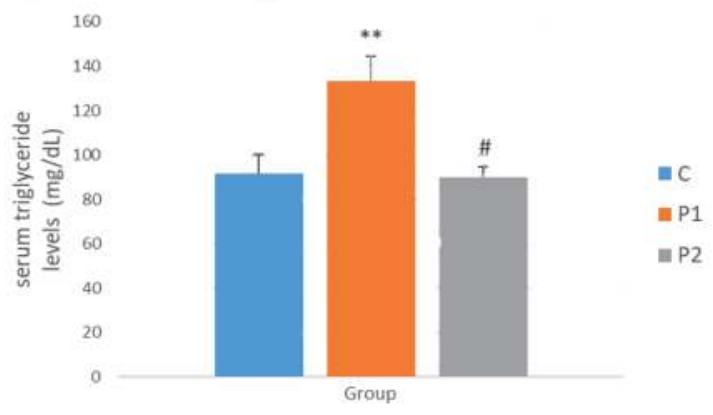

Figure 1. Graph of serum total cholesterol (a) and triglyceride levels (b) in each group (Cont.)

Note: C: control group; P1: atherosclerosis-induced group; P2: atherosclerosis-induced group and given bortezomib. ${ }^{*} p=0.002$ versus $C,{ }^{* *} p=0.022$ versus $C, \# p=0.043$ versus $P 1$

The lowest and highest mean triglyceride levels were observed in the group of control (C) $(49.7 \pm 13.6)$ and the group of atherosclerosis (P1) (133.41 \pm 11.3$)$, respectively. The mean level of serum triglyceride for atherosclerosis+bortezomib group (P2) was $89.82 \pm 4.9$ $\mathrm{mg} / \mathrm{dl}$. Rats on atherosclerosis group had significantly higher mean triglyceride levels than rats in the group of control $(p=0.022)$ The difference of serum triglyceride was also significant between atherosclerosis+bortezomib group (P2) and atheroscierosis group (P1) ( $p=0.043)$ (Figure 1B).

\section{Abdominal Aortic Histopathology}

Histopathological observations of abdominal aorta showed the highest score of atherosclerosis in the atherosclerosis group, while the lowest was in the control group. Bortezomib $50 \mu \mathrm{g} / \mathrm{kgBW} /$ day on day 1 and 3 showed lower scores than atherosclerotic conditions but still higher than normal conditions (Table 1).

Table 1. The mean scores of abdominal aortic histopathological features

\begin{tabular}{lrrr}
\hline Replication & \multicolumn{2}{c}{ Group } \\
\cline { 2 - 4 } & Control & Atherosclerosis & $\begin{array}{c}\text { Atherosclerosis+ } \\
\text { Bortezomib }\end{array}$ \\
\hline 1 & 0 & 1.11 & 1.00 \\
2 & 0 & 0.44 & 0.44 \\
3 & 0.22 & 1.00 & 0.67 \\
4 & 0.11 & 1.22 & 0.56 \\
5 & 0.22 & 0.78 & 0.44 \\
6 & 0.56 & 0.44 & 0.88 \\
\hline Mean \pm SD & $0.18 \pm 0.09$ & $0.83 \pm 0.1^{\mathrm{a}}$ & $0.67 \pm 0.1$ \\
\hline
\end{tabular}

Note: $a=p<0.05$ compared to group $C$
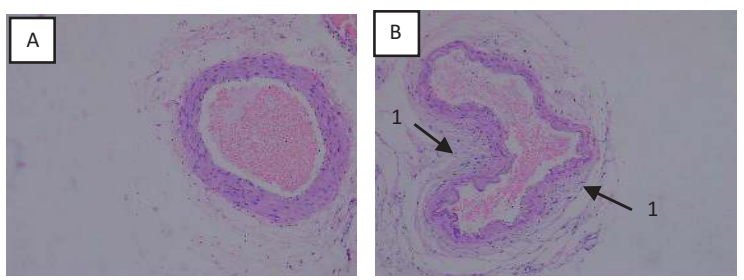

Figure 2. Abdominal aortic histopathology (A, B, C: HE, 100x) D: HE 400x 

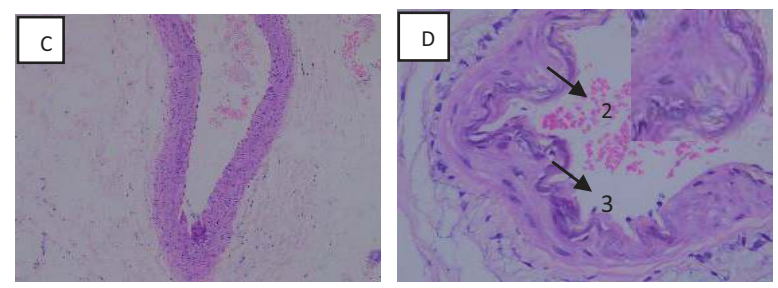

Figure 2. Abdominal aortic histopathology (A, B, C: HE, 100x) D: HE 400x

Note: A: control group; B: atherosclerosis group; C: atherosclerosis + bortezomib group: $\mathrm{D}$ : atherosclerosis group

1: aortic wall thickness; 2 : foam cell; 3 : calcification

The results of histopathological examination in atherosclerosis-induced groups mostly showed thickening blood vessel walls (Figure 2B). Most of the experimental animals in the atherosclerosis group were in the early stages of progression, which was characterized by smooth muscle proliferation and calcification, but not in all fields of view. The atherosclerosis group treated with bortezomib showed milder atherosclerotic lesions (Figure 2C).

\section{DISCUSSION}

The results showed that intraperitoneal administration of bortezomib dose $50 \mu \mathrm{g} / \mathrm{kgBW} /$ day on day 1 and 3 and followed by observation on the day 4 did not reduce the atherosclerosis score to the normal conditions. This was different from the study by Wilck et al. (14) that suggested the administration of bortezomib $50 \mu \mathrm{g} / \mathrm{kg}$ for six weeks in LDLR -/- rats suppressed the formation of early atherosclerotic lesions. This difference was possible because of the differences in the model of atherosclerosis used, the stage of atherosclerosis, and the length of bortezomib administration. Atherosclerosis induction in this study was carried out by administering vitamin D3 and an atherogenic diet ( $2 \%$ cholesterol, $5 \%$ goat fat, $0.2 \%$ cholic acid) for four days. This was based on consideration by using the atherosclerosis induction technique; progression stage of atherosclerosis was found because proteasome expression in the abdominal aorta was the highest at the progression stage (9). Most experimental animals were found to be at the progression stage that was marked by the proliferation of smooth muscle cells in the intima and calcification (7). Administration of a low dose of proteasome inhibitor for four days was not enough to inhibit the work of proteasomes at this progression stage. This can be seen from the reduction in the score of atherosclerotic lesions in the atherosclerosis group that was given bortezomib compared to the atherosclerosis group but was not statistically significant. The study by Wilck et al. (15) also found that administration of bortezomib at a dose of $50 \mu \mathrm{g} / \mathrm{kg}$ for six weeks in LDLR -/- rats with advanced atherosclerotic lesions (complication stage) gave no therapeutic effect. This indicates that the administration of proteasomes inhibitors at the same dose but at different stages of atherosclerosis could give different results.

The total cholesterol level in the atherosclerosis group was higher than that in the control group. Increased level of blood cholesterol (hypercholesterolemia) and, more specifically, an increase in low-density lipoprotein (LDL) concentrations are important factors for atherosclerosis.
Hypercholesterolemia is associated with an increase in LDL transcytosis which subsequently accumulates in the subendothelial space and undergoes oxidation to form oxidized LDL (oxLDL). Low-density oxidized lipoproteins are markers of atherosclerosis that are detected during the atherosclerosis stage and are associated with endothelial cell damage, inflammation, and oxidative stress (12). Bortezomib dose of $50 \mu \mathrm{g} / \mathrm{kg}$ in this study could not prevent an increase in total cholesterol levels due to the induction of atherosclerosis conducted; this is in line with the study of Wilck et al. $(14,15)$ that the administration of $50 \mu \mathrm{g} / \mathrm{kg}$ bortezomib dose did not affect total cholesterol levels. The mechanism of anti-atherosclerosis bortezomib is thought to be through a mechanism of reducing oxidative stress and anti-inflammation (14). In contrast, the study by Oliva, et al. (17) showed that bortezomib suppressed endogenous cholesterol synthesis in rats induced by steatosis with ethanol.

The serum triglyceride level in the atherosclerosis group was higher than that in the control group. High blood triglyceride level causes changes in the size, density, distribution, and composition of LDL to become a more atherogenic smalldense LDL (18). The administration of bortezomib at a dose of $50 \mu \mathrm{g} / \mathrm{kg}$ in this study could prevent an increase in serum triglyceride levels in atherosclerotic-induced rats. This study in line with research by Oliva, et al. showed that bortezomib suppressed fatty acid synthesis in rats induced by steatosis with ethanol (17). In contrast, Wilck, et al. showed Bortezomib treatment had no effect on triglyceride levels. The mechanism of anti-atherosclerosis bortezomib is mainly through its role in reducing oxidative stress and inflammation (14).

Proteasomes play a role in various biological processes such as inflammation, proliferation, and apoptosis, which are important parts at the initiation stage, the progression stage, and the atherosclerotic complication stage. Most of these proteasome roles are through the regulation of NFB, which further regulates the expression of various genes. On the other hand, proteasomes also protect cells by destroying damaged proteins (control of protein quality). This situation results in the dualism of the role of proteasomes in oxidative stress. Low oxidative stress will increase proteasome activity, whereas high oxidative stress levels will inhibit proteasome activity (7). Research by Ismawati, et al. (9) found differences in proteasome expression at each stage of atherosclerosis, and proteasome expression was the highest in the progression stage. The use of proteasome inhibitors can have therapeutic effects but can also be the opposite. Proteasome barriers do not only affect one protein or one pathway. Some factors that influence the effect of proteasome inhibitors are dose, administration duration, proteasome target subunit composition, and atherosclerotic stage. The same dose inhibitor, if used at different stages of atherosclerosis, will give different results. Administering low-dose proteasome inhibitors will have a beneficial effect, but the effect will be lost if the dose is increased (19).

The administration of proteasome inhibitors in this study did not show the possible anti-atherosclerotic effect because the proteasome expression at the progression stage was higher than the initiation stage of atherosclerosis (9) so that a proteasome inhibitor with a higher or longer dose was needed. A higher dose of 
proteasome inhibitor will be detrimental, so another option is to provide a low dose proteasome inhibitor with a longer duration of time. The atherosclerosis model in this study used atherosclerosis induction for four days for the progression stage and two weeks for the complication stage (9), which shows that the atherosclerosis progression stage model is still obtained if the treatment is

\section{REFERENCE}

1. Barquera S, Pedroza-Tobías A, Medina C, et al. Global Overview of the Epidemiology of Atherosclerotic Cardiovascular Disease. Archives of Medical Research. 2015; 46(5): 328-338.

2. Badan Penelitian dan Pengembangan Kesehatan Kementerian Kesehatan RI. Riset Kesehatan Dasar 2013. Jakarta: Kementrian Kesehatan Republik Indonesia; 2013.

3. Dabek J, Kułach A, and Gasior Z. Nuclear Factor Kappa-Light-Chain-Enhancer of Activated B Cells (NF-KB): A New Potential Therapeutic Target in Atherosclerosis? Pharmacological Reports. 2010; 62(5): 778-873.

4. Fava C and Montagnana M. Atherosclerosis is an Inflammatory Disease Which Lacks a Common AntiInflammatory Therapy: How Human Genetics Can Help to This Issue. A Narrative Review. Frontiers in Pharmacology. 2018; 9: 1-9.

5. Wu JT and Wu LL. Association of Soluble Markers with Various Stages and Major Events of Atherosclerosis. Annals of Clinical \& Laboratory Science. 2005; 35(3): 240-250.

6. Mizuno Y, Jacob RF, and Mason RP. Inflammation and the Development of Atherosclerosis. Journal of Atherosclerosis and Thrombosis. 2011; 18(5): 351-358.

7. Herrmann J, Lerman LO, and Lerman A. On to the Road to Degradation: Atherosclerosis and the Proteasome. Cardiovascular Research. 2010; 85(2): 291-302.

8. Jung T, Catalgol B, and Grune T. The Proteasomal System. Molecular Aspects of Medicine. 2009; 30(4): 191-296.

9. Ismawati, Oenzil F, Yanwirasti, and Yerizel E. Changes In Expression of Proteasome in Rats at Different Stages of Atherosclerosis. Anatomy \& Cell Biology. 2016; 49(2): 99-106.

10. Eldridge AG and O'Brien T. Therapeutic Strategies Within the Ubiquitin Proteasome System. Cell Death and Differentiation. 2010; 17(1): 4-13. continued until less than two weeks.

In short, the administration of $50 \mu \mathrm{g} / \mathrm{kg}$ bortezomib for four days in rats model of progression stage of atherosclerosis can decrease serum triglyceride levels, although it can not inhibit the formation of atherosclerotic lesions and has no effect on serum total cholesterol and serum triglyceride levels.

11. Chen D, Frezza M, Schmitt S, Kanwar J, and Dou QP. Bortezomib as the First Proteasome Inhibitor Anticancer Drug: Current Status and Future Perspectives. Current Cancer Drug Targets. 2011; 11(3): 239-253.

12. Li X, Wood TE, Sprangers $\mathrm{R}$, et al. Effect of Noncompetitive Proteasome Inhibition on Bortezomib Resistance. Journal of the National Cancer Institute. 2010; 102(14): 1069-1082.

13. Ludwig A, Fechner M, Wilck N, et al. Potent AntiInflammatory Effects of Low-Dose Proteasome Inhibition In The Vascular System. Journal of Molecular Medicine. 2009; 87(8): 793-802.

14. Wilck N, Fechner M, Dreger $\mathrm{H}$, et al. Attenuation of Early Atherogenesis in Low-Density Lipoprotein Receptor-Deficient Mice by Proteasome Inhibition. Arteriosclerosis, Thrombosis, and Vascular Biology. 2012; 32(6): 1418-1426.

15. Wilck N, Fechner M, Dan C, Stangl V, Stangl K, and Ludwig A. The Effect of Low-Dose Proteasome Inhibition on Pre-Existing Atherosclerosis in LDL Receptor-Deficient Mice. International Journal of Molecular Sciences. 2017; 18(4): 1-10.

16. Ismawati, Asni E, Mukhyarjon, and Romus I. Alpha Lipoic Acid Inhibits Expression of Intercellular Adhesion Molecule-1 (ICAM-1) in Type 2 Diabetic Mellitus Rat Models. The Indonesian Biomedical Journal. 2020; 12(1): 40-44.

17. Oliva J, French SW, Li J, and Bardag-Gorce F. Proteasome Inhibitor Treatment Reduced Fatty Acid, Triacylglycerol and Cholesterol Synthesis. Experimental and Molecular Pathology. 2012; 93(1): 26-34.

18. Reddy HK, Laxmikanth B, Sujatha P, and Modi P. A Study Of Hs-CRP and Lipid Profile in Overweight Individuals. International Journal of Medical Science and Public Health. 2013; 2(2): 399-403.

19. Wilck $\mathrm{N}$ and Ludwig A. Targeting the UbiquitinProteasome System in Atherosclerosis: Status Quo, Challenges, and Perspectives. Antioxidants \& Redox Signaling. 2014; 21(17): 2344-2363. 